\title{
ANALYSIS OF THE ASSOCIATION OF A HEAT SHOCK PROTEIN70-1 GENE PROMOTER POLYMORPHISM WITH MYOCARDIAL INFARCTION AND CORONARY RISK TRAITS
}

\author{
M.K. BOLLA', G.J. MILLER ${ }^{2}$, D.M. YELLON ${ }^{3}$, A. EVANS ${ }^{+}$, G. LUC ${ }^{5}$, J.P. CAMBOU ${ }^{6}$, \\ D. ARVEILER ${ }^{7}$, F. CAMBIEN ${ }^{8}$, D.S. LATCHMAN", S.E. HUMPHRIES', I.N.M. DAY' \\ 'Cardiovascular Genetics, Department of Medicine, University College London Medical School, The \\ Rayne Institute, 5 University Street, London WCIE 6JJ, UK \\ ${ }^{2}$ MRC Epidemiology and Medical Care Unit, Wolfson Institute of Preventive Medicine, The Medical \\ College of St. Bartholomew's Hospital, Charterhouse Square, London ECIM 6BQ, UK \\ ${ }^{8}$ Division of Cardiology, Hatter Institute for Cardiovascular Studies, University College Hospital, \\ Grafton Way, London WCl, UK. \\ ${ }^{4}$ MONICA project, Belfast, UK \\ ${ }_{5} M O N I C A$ project, Lille, France \\ ${ }^{6} \mathrm{MONICA}$ project, Toulouse, France \\ ${ }^{7} M O N I C A$ project, Strasbourg, France \\ ${ }^{8}$ INSERM, SC7-17, rue du Fer à Moulin, 75005 Paris, France \\ "Department of Molecular Pathology, Windeyer Building, Cleveland Street, London WCIP 6DB, UK
}

\section{SUMMARY}

Heat shock proteins (HSP) are induced during coronary ischaemia, and abnormal expression of one HSP gene may cause hypertension in rats. We examined association of a promoter polymorphism in the major stress-inducible hsp70 gene (hsp70-1 or HSP70A1) on chromosome 6 (p21.3) with coronary disease traits. This $\mathrm{C} \rightarrow \mathrm{A}$ base substitution (AAACCCC) is at nucleotide position -110 in the heat shock transcription factor binding site (heat shock element, HSE). The first study sample (ECTIM), recruited from Belfast and three centres in France, consisted of 578 myocardial infarction cases and 698 agematched controls. The frequency of the $\mathrm{A}_{-110}$ allele was $0.381(95 \% \mathrm{CI}=0.35-0.41)$ and $0.384(95 \%$ $\mathrm{CI}=0.36-0.41)$ in cases and controls respectively. Homozygotes for the rarer $\mathrm{A}_{-110}$ allele had a higher BMI $\left(27.3 \mathrm{~kg} / \mathrm{m}^{2} \pm 3.9\right)$ compared with homozygotes for the common $\mathrm{C}_{-110}$ allele $\left(26.3 \mathrm{~kg} / \mathrm{m}^{2} \pm 3.3\right)$. The rarer homozygotes were shorter and heavier than the common homozygotes. A follow-up study involved 1431 healthy, middle aged men from the UK (NPHS II group). The frequency of the $\mathrm{A}_{-110}$ allele was $0.385(95 \% \mathrm{CI}=0.37-0.40)$, and there was no association of genotype with BMI. Thus there appears to be no strong association of the $\mathrm{Hsp} 70-1$ promoter polymorphism with risk of myocardial infarction, $\mathrm{BMI}$ or any coronary disease traits analysed here.

KEY WORDS Heat shock protein Myocardial infarction Polymorphism Coronary disease

\section{INTRODUCTION}

The heat shock response was originally discovered by Ritossa (1962) in Drosophila busckii, in response to heat, and, subsequently is was shown (Tissieres et al., 1974) that

Correspondence to: M.K. Bolla, Cardiovascular Genetics, Department of Medicine, University College London Medical School, The Rayne Institute, 5 University Street, London WC1E 6JJ, UK. Tel.: +44 171 2096962, Fax: +44 171209 6212; Email: rmhaseh@ucl.ac.uk 
the appearance of chromosome puffs coincided with the synthesis of a small number of proteins, the heat shock proteins. Heat shock proteins are now known to be induced by a diverse array of cellular stresses other than elevated temperature, including those that are encountered during myocardial ischaemia. The function of this response has not been determined. One hypothesis (Pelham, 1986) suggest that heat shock proteins protect cellular proteins against denaturation during heat shock.

The hsp70 family of stress proteins is one of the most predominant and highly conserved throughout evolution. The major heat inducible hsp70 gene, hsp70-1 (HSP70A1), is located between two other hsp70 genes (hsp70-2 and hsp70-hom) in the major histocompatibility complex (MHC) class III region of chromosome 6 at $6 \mathrm{p} 21.3$ (Harrison et al., 1987; Sargent et al., 1989; Milner and Campbell, 1990; Campbell and Trowsdale, 1993). The transcriptional control of hsp70-1 is complex and the 5' flanking region of the gene contains binding sites for a number of transcription factors, including TFIID, AP2, ATF, and Sp1, as well as CCAAT and purine-rich box motifs. However, a distinct control element, the heat shock element (HSE), is located further upstream (Cunniff et al., 1991). Upon exposure to stressful stimuli, oligomerization of proteins called heat shock factors (HSF) occurs and, binding to the HSE in the promoter, initiates transcription of the gene. The HSE contains three NGAAN motifs that form a primary high affinity HSF binding site (Abravaya et al., 1991). Located five bases upstream of the first of these motifs is a $\mathrm{C} \rightarrow \mathrm{A}$ polymorphism (Cascino et al., 1993) at nucleotide position -110 (Fig.1).

In 1986 Murry et al. (Murry et al., 1986) first described a phenomenon in dogs, now known as ischaemic preconditioning. In 1988, Currie et al. (Currie et al., 1988) demonstrated the protective effect in ischaemia and reperfused myocardium following heat shock. This subject has been reviewed in detail (Yellon and Marber, 1994). These and other studies (Currie and White, 1983; Currie, 1987; Yellon et al., 1992; Marber et al., 1993) have shown an increased synthesis of hsp70 in cardiac tissue from a variety of different species. Increased levels of hsp70 in ischaemia are paralleled by increased abundance of its corresponding mRNA, although the level of other mRNAs decline during ischaemia, again paralleling the processes occurring during heat shock.

Heat shock proteins can be induced in several cardiovascular cell types, including aortic smooth muscle cells, myocardial cells, and cardiac mesenchymal cells. Normal human aortas have been demonstrated, by immunostaining, to have a homogenous distribution of hsp70 throughout the intima-media. Human atherosclerotic aortas, however, have increased hsp70 staining around areas of necrosis (typically in the central portions of atheromas) which coincides with plaque lipid accumulations (Berberian et al., 1990). Examination of the cellular nature of the plaques show increased hsp70 staining in macrophages around areas of necrosis (Johnson et al., 1995).

Hsp70 expression has also been implicated in hypertension (Hamet et al., 1990a; Hamet et al., 1990c; Hamet, 1992; Hamet et al., 1994). Genetically hypertensive animals are more sensitive to heat stress than normotensive controls, and thermosensitivity cosegregates with a component of high blood pressure in cross- and back- bred animals. Elevated hsp70 gene expression has been demonstrated (Hamet et al., 1990b) in cultured cells from spontaneously hypertensive rats (SHR) and mice (SHM), resulting in increased transcription of hsp70 mRNA. Furthermore, there is a higher accumulation of hsp70 mRNA in lymphocytes from hypertensive humans than in normotensive humans when subjected to heat stress at $42^{\circ} \mathrm{C}$ (Kunes et al., 1992). 


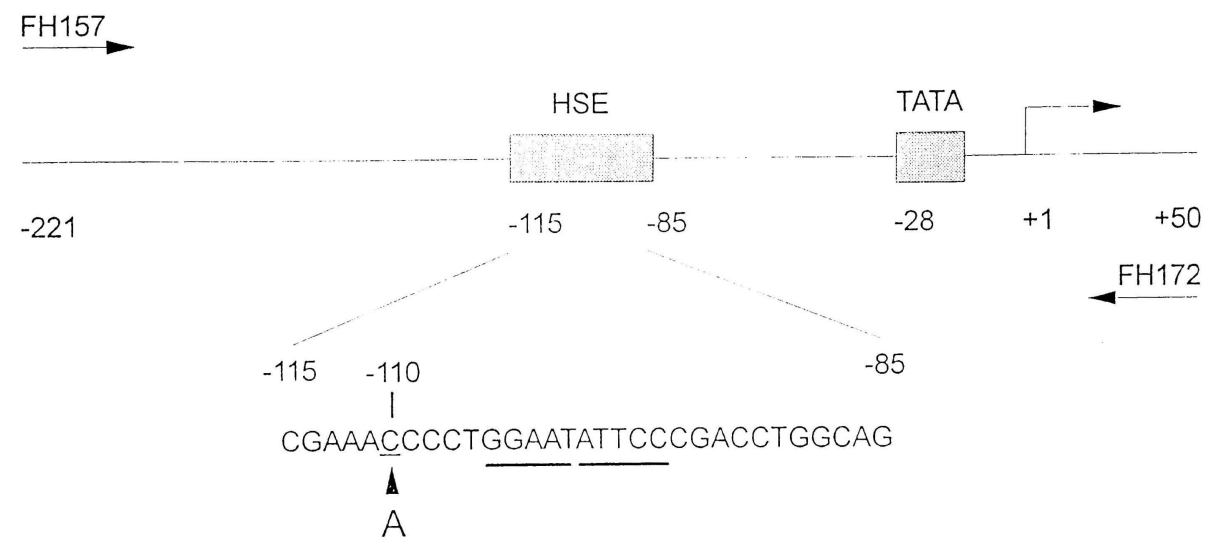

Figure 1 Schematic to show the polymorphism $\left(\mathrm{C}_{-110}\right.$ to $\left.\mathrm{A}_{-110}\right)$ in the HSP70-1 promoter. Arrows indicating the PCR primers FH157 and FH172 are shown. Position +1 represents the start site of transcription. TATA - TATA box; HSE - heat shock element. Thick lines show the motifs that form the high affinity binding site for HSF (heat shock factor).

On these grounds, analysis for polymorphism in the hsp70 genes and search for allelic association with coronary disease and coronary traits was considered to be worthwhile. Here we describe such a study, for a common polymorphism in the heat shock element in the promoter region of the main human hsp70 gene, HSP70A1.

\section{MATERIALS AND METHODS}

\section{Subjects}

The ECTIM (Etude CasTemoins de l'Infarctus du Myocarde) population-based casecontrol study is located in four regions of Europe (Belfast, Toulouse, Lille and Strasbourg) participating in the World Health Organisation MONICA project. The study includes male MI survivors aged between 25 and 64, and male age matched controls (Parra et al., 1992). A total of 1276 subjects from the ECTIM study (578 cases and 698 controls) were screened for the Hsp70-1 polymorphism.

The NPHS II (Northwick Park Heart Study) group is a prospective study of 3179 healthy men, aged 50-61 years, who are being followed for five years, with annual measures of lipids and clotting factors (Miller et al., 1996). From this study an unselected subset of 1431 men was analysed for the Hsp70-1 polymorphism. 


\section{DNA Analysis}

ECTIM DNA was extracted from whole blood by the phenol-chloroform method (Kunkel et al., 1997). NPHS II DNA was extracted from whole blood using the salting out method (Miller et al., 1988). The stock DNA was diluted to a concentration of approximately 10ng/ $\mu \mathrm{l}$ and stored in deep 96-well Beckman microplates. These were used to transfer $2.5 \mu \mathrm{l}$ of each DNA into its corresponding coordinate of a 96-well Omniplate, to the very base of the well. The DNA was allowed to dry and than stored at room temperature until required for PCR.

PCR was carried out in $20 \mu$ reactions under $20 \mu$ paraffin. Each PCR reaction contained 0.8 pmole of each PCR primer, deoxynucleotides $(0.2 \mathrm{mM}$ dATP etc., $0.02 \mathrm{mM}$ $\mathrm{dCTP}$ ), buffer (10mM tris pH8.5, 50mM KCl, $0.001 \%$ w/v gelatin), $1.5 \mathrm{mM} \mathrm{MgCl}_{2}$, wl $(0.05 \% \mathrm{w} / \mathrm{v})$, Taq polymerase $(0.2 \mathrm{units})$ and radioisotope $\left(0.03 \mu \mathrm{Ci}\left[\alpha-{ }^{32} \mathrm{P} \mathrm{dCTP}\right) . \mathrm{PCR}\right.$ primer sequences for the HSP70A1 promoter region were:

\section{5'-CCCTGTCCCCTCCAGTGAATC (sense, "FH157") \\ 5'-biotin-CTCGAAAAAGGTAGTGGACTG (antisense, "FH172")}

PCR cycling conditions used were as follows: $95^{\circ} \mathrm{C}$ for 5 minutes; $95^{\circ} \mathrm{C}$ for 1 minute, $55^{\circ} \mathrm{C}$ for 1 minute, $72^{\circ} \mathrm{C}$ for 1 minute $(35$ cycles $)$; and $72^{\circ} \mathrm{C}$ for 5 minutes.

\section{Single Strand Conformational Polymorphism (SSCP)}

$2.0 \mu \mathrm{l}$ of the PCR product was added to $6.0 \mu \mathrm{l}$ of a 7:5 ratio of formamide dye mix (95\% formamide, $10 \mathrm{mM}$ EDTA, and $0.025 \%$ each of bromophenol blue and xylene cyanole FF) and a solution of $0.1 \%(\mathrm{w} / \mathrm{v})$ sodium dodecylsulphate (SDS) containing $10 \mathrm{mM}$ EDTA. The DNA was denatured at $95^{\circ} \mathrm{C}$ for 5 minutes and cooled immediately on wet ice. A $7.5 \%$ polyacrylamide non-denaturing gel (ratio of acrylamide to bisacrylamide of $49: 1$ ) of size $330 \mathrm{~mm} \times 390 \mathrm{~mm} \times 0.35 \mathrm{~mm}$ in $1 \times$ Tris-borate-EDTA (TBE, pH8.3) buffer with 5\% glycerol and 10mM EDTA was used for SSCP. $4.0 \mu \mathrm{l}$ of each sample from the first column loaded onto the gel using the 8-channel multipipette which loads every alternate well. The second column of samples was then loaded intercalated with the first column. A space of two empty wells was left before loading column three as before. In this way half the samples (six columns) were loaded onto the gel. Electrophoresis was carried out at $300 \mathrm{~V}$ overnight (about 20 hours) at room temperature (usually $21-25^{\circ} \mathrm{C}$ ).

An autoradiogram of the gel showed the presence of a polymorphism which was sequenced and confirmed to being the $\mathrm{C} \rightarrow \mathrm{A}$ base substitution at nucleotide -110 . Furthermore, SSCP of 96 samples showed that the samples could be genotyped from the non-denatured double stranded PCR product. In order to genotype rapidly the large number of samples, polyacrylamide gel electrophoresis was carried out on the undenatured PCR product. Thus, $2.0 \mu \mathrm{l}$ of each PCR sample was transferred to $6.0 \mu \mathrm{l}$ of formamide dye mix, and, $4.0 \mu \mathrm{l}$ of each sample was loaded, using the 8-channel multipipette, onto a $7.5 \%$ polyacrylamide gel as before. The samples were run into the gel at $800 \mathrm{~V}$ for approximately 30 minutes before loading the remaining 46 samples in exactly the same manner. This procedure was repeated for up to eight separate loadings (4 x 96 samples). After the last loading the gel was run at $300 \mathrm{~V}$ for about 20 hours. An autoradiogram of the gel was obtained and the samples genotyped for the HSP 70-1 polymorphism. 


\section{Statistical analysis}

Statistical analysis was carried out using SPSS PC+, SAS and Microsoft Excel computer software. Analysis of variance was used to assess the effect of genotype, centre, disease status and their various interactions with BMI, systolic and diastolic blood pressures, and pulse pressure. A $\chi^{2}$-test was used to compare the observed numbers of each genotype with those expected for a population in Hardy-Weinberg equilibrium. Ninety-five percent confidence intervals (95\% C.I.) for population allele frequencies were calculated from sample allele frequencies, based on the approximation of the binomial and Normal distributions when $n$ is large. The critical ratio with continuity correction, also based on the binomial-normal distribution approximation, was calculated to test the significance of the difference between two population allele frequencies. Association between disease status and genotype was assessed by calculation of the odds ratio. In all statistical tests, a $\mathrm{P}$-value $<0.05$ was taken as indicating statistical significance.

\section{Results}

SSCP of the hsp70-1 gene promoter $(-221 \mathrm{bp}$ to $+50 \mathrm{bp})$ showed the presence of only one common polymorphism. Sequencing confirmed that the SSCP is created by the previously reported $\mathrm{C} \rightarrow \mathrm{A}$ change at position -110 . Although conferring no size difference, the $\mathrm{A}_{-110}$ allele migrates at a slightly faster rate (relative mobility 1.017) than the $\mathrm{C}_{-110}$ allele under the conditions used. Furthermore, the heteroduplexes in heterozygote PCR products have greater mobilities again (relative mobilities 1.023, 1.029). It has been shown, by computer modelling (De Santis et al., 1988), that the presence of the A allele increases the curvature of the DNA and thus retards the A allele on an electrophoretic gel. This phenomenon allowed easy and rapid genotyping from the autoradiograms. (Fig.2).

In the ECTIM group, the total number of control individuals (and patients) with the genotypes CC, CA and AA were 274 (225), 312 (265) and 112 (88) respectively. The number of control individuals (and patients) with the genotypes CC, CA and AA in the four centres were found to be: Strasbourg 77 (73), 99 (85) and 26 (42); Toulouse 76 (55), 91 (76) and 41 (11); Lille 49 (22), 44 (30) and 17 (7); Belfast 72 (75), 78 (74) and 28 (28) respectively. The genotype frequency did not differ significantly between centres and all centres were found to be in Hardy-Weinberg equilibrium. Overall, the frequency of the $\mathrm{A}_{-110}$ allele in patients $(0.381$ [95\% CI $\left.=0.35-0.41]\right)$ was similar to that found in the controls $(0.384$ [ $95 \% \mathrm{CI}=0.36-0.41])$. The genotype frequency for this polymorphism obtained here is similar to that obtained in a previous study (Cascino et al., 1994).

The ECTIM group was analysed for association of HSP70A 1 C/A ${ }_{-110}$ genotype with hypertension (systolic and diastolic blood pressures, and, pulse pressure) and BMI. Analysis of the ECTIM group showed an association with BMI in both patients and controls (Table 1). A higher BMI $(\mathrm{p}<0.05)$ was observed in the AA homozygote $[27.6 \mathrm{~kg} /$ $\mathrm{m}^{2} \pm 0.38$ in patients and $27.1 \mathrm{~kg} / \mathrm{m}^{2} \pm 0.40$ in controls] than in the CC homozygote $[26.3$ $\mathrm{kg} / \mathrm{m} 2 \pm 0.22$ in patients and $26.2 \mathrm{~kg} / \mathrm{m} 2 \pm 0.20$ in controls]. Heterozygotes were found to have an intermediate BMI. More detailed examination showed that the group of AA homozygotes were on average shorter compared with the $\mathrm{CC}$ homozygotes.

Since this association with BMI may have been a chance observation, genotype was determined in a randomly selected group of 1431 healthy men from the UK, of similar age to the ECTIM control group. In the NPHS II group, the total number of individuals 


\section{LOADING}

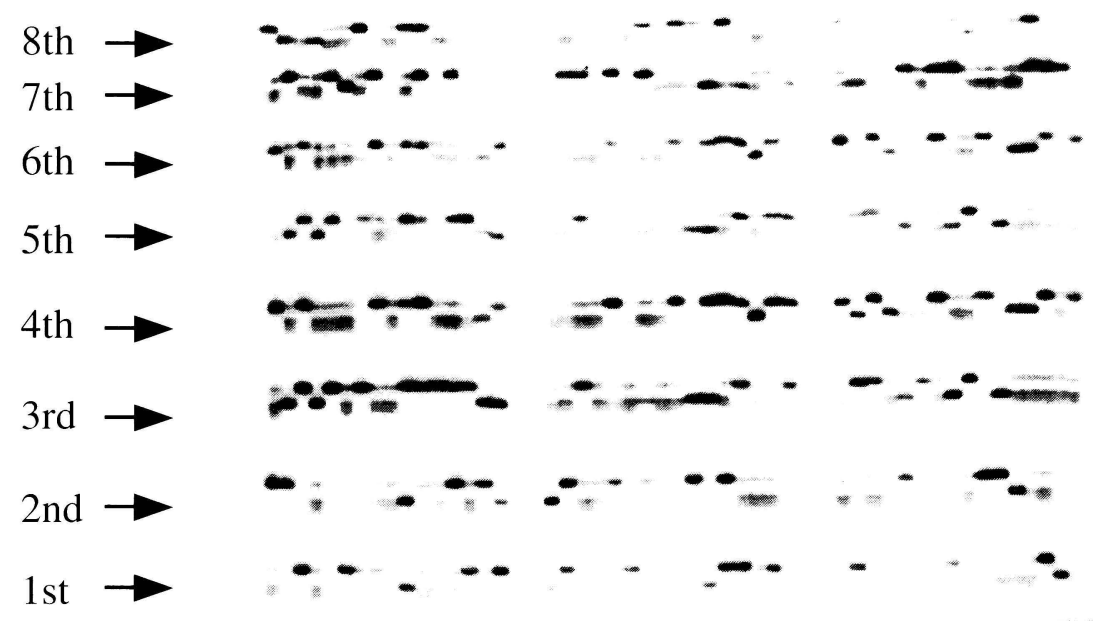

Figure 2 Autoradiogram of single polyacrylamide gel analysis of 384 samples for the HSP70-1 promoter C/A single nucleotide polymorphism at -110 . The autoradiogram shows eight repeated loadings of the gel (48 samples ie. half a 96-well microtitre plate per loading), as described in methods. The first three tracks in the 8th loading show respectively: upper homoduplex only $(\mathrm{C} / \mathrm{C}$ homozygote), lower homoduplex only (A/A homozygote), or both homoduplexes and two heteroduplexes migrating in advance of the A/A homoduplex (C/A heterozygote).

Table 1 Analysis of BMI, height and weight with HSP70-1 genotype in patients and controls in the ECTIM group.

\begin{tabular}{|c|c|c|c|c|c|c|c|}
\hline \multirow[b]{3}{*}{ (Number) } & \multicolumn{6}{|c|}{ Genotype } & \multirow{3}{*}{ P Value } \\
\hline & \multicolumn{3}{|c|}{ Patients } & \multicolumn{3}{|c|}{ Controls } & \\
\hline & $\mathrm{CC}(225)$ & $\mathrm{CA}(265)$ & $\mathrm{AA}(88)$ & $\mathrm{CC}(274)$ & CA (312) & $\mathrm{AA}(112)$ & \\
\hline $\operatorname{BMI}\left(\mathrm{kg} / \mathrm{m}^{2}\right)$ & $26.3 \pm 0.22$ & $26.6 \pm 0.22$ & $27.6 \pm 0.38$ & $26.2 \pm 0.20$ & $26.5 \pm 0.23$ & $27.1 \pm 0.40$ & 0.004 \\
\hline Height (cm) & $171.6 \pm 0.45$ & $171.1 \pm 0.37$ & $170.7 \pm 0.64$ & $173.5 \pm 0.41$ & $173.5 \pm 0.36$ & $171.9 \pm 0.68$ & 0.048 \\
\hline Weight (kg) & $77.6 \pm 0.71$ & $77.9 \pm 0.69$ & $80.4 \pm 1.29$ & $79.1 \pm 0.71$ & $79.8 \pm 0.74$ & $80.3 \pm 1.29$ & 0.203 \\
\hline
\end{tabular}


Table 2 Analysis of BMI, height and weight with HSP70-1 genotype in the NPHS II group.

\begin{tabular}{l|r|r|r|c}
\hline & \multicolumn{4}{|c}{ Genotype } \\
\hline Number) & CC (544) & CA (671) & AA (216) & P Value \\
\hline BMI $\left(\mathrm{kg} / \mathrm{m}^{2}\right)$ & $26.3 \pm 0.15$ & $26.5 \pm 0.14$ & $26.4 \pm 0.23$ & 0.63 \\
Height $(\mathrm{cm})$ & $174.7 \pm 0.28$ & $174.7 \pm 0.26$ & $174.0 \pm 0.45$ & 0.39 \\
Weight $(\mathrm{kg})$ & $80.4 \pm 0.48$ & $81.0 \pm 0.47$ & $80.0 \pm 0.80$ & 0.43 \\
\hline
\end{tabular}

with the genotypes CC, CA and AA were 544, 671 and 216 respectively. The NPHS II group showed a similar frequency of the $\mathrm{A}_{-110}$ allele $(0.385$ [95\% $\left.\mathrm{CI}=0.37-0.40]\right)$ as in the ECTIM sample. Analysis of the NPHS II group, however, showed no significant association to the Hsp70-1 genotype with BMI (table 2). The average age of the individuals in the two studies was similar and, therefore, does not account for the difference observed in the ECTIM study. Blood pressure indices were studied in the NPHS II group and showed no association.

\section{DISCUSSION}

The single nucleotide polymorphism analysed is unusual in that the PCR homoduplexes show slightly different electrophoretic mobility, apparently due to induced DNA curvature (Cascino et al., 1993). This phenomenon was exploited to achieve an unusual but rapid approach to genotyping (Fig. 2).

Based on its known role in physiology and data showing expression in atherosclerotic tissues (Berberian et al., 1990) and in ischaemic preconditioning (Marber et al., 1993), hypothesis was that a polymorphism in the hsp70-1 gene might associate with blood pressure or myocardial infarction. No association was found. The association between the hsp70-1 polymorphism and BMI in this group was unexpected. The association mainly represented as lower height, was seen in both cases and controls and was evident in all centres, but was not observed in a follow-up study of a large group of similarly aged healthy men from the UK. There is no information within the data upon which to judge the relative reliability or representativeness of the two studies. However, the absence of association in NPHS II questions the real significance of the results of ECTIM, and points to the need for further study in other population samples. Although the ECTIM data presented here does not support the involvement of the Hsp70-1 gene in contributing to the risk of myocardial infarction, a complete test of our hypothesis would demand the identification of all common polymorphisms in each and every hsp gene and their typing in the study group supplemented also with family-based studies. In the interim, association studies, although known (Risch and Merikangas, 1996) to offer greater power than allele sharing (linkage) studies, are selective rather than systematic. Selection can at best increase the chance of identifying a genetic variation influencing a trait, for example based on function of the gene product, the identification of variation in protein sequence, and the identification of variation in regions proven to regulate expression level etc, such 
as promoter regions. In the absence of such apparent sites, variations which will lead to the definition of haplotypes and which will act as linkage disequilibrium markers for aetiological sites, must be identified and used. The variant studied in the hsp70-1 gene promoter heat shock element is of conceivable but not proven effect on expression. It was applicable here as an initial partition of the groups of haplotypes at this locus. Very few (we do not know of any) initial studies define all haplotypes as they are contingent on extensive scanning for all polymorphism across a locus, but the present work represents part of a program of this laboratory to develop this technology to a level of systematic rather than candidate gene studies (Day et al., 1996).

\section{ACKNOWLEDGEMENTS}

MB was supported by a University College London Medical School/special trustees of the Middlesex Hospital and University College Hospital grant to SEH, DSL, DMY. INMD was supported by a BHF intermediate fellowship. SEH is supported by a BHF chair award programme grant.

\section{REFERENCES}

Abravaya, K., Phillips, B., Morimoto, R.I. (1991). Heat shock-induced interactions of heat shock transcription factor and the human hsp70 promoter examined by in vivo footprinting. Mol. Cell. Biol., 11, 586-592.

Berberian, P.A., Myers, W., Tytell, M., Challa, V., Bond, M.G. (1990). Immunohistochemical localization of heat shock protein-70 in normal-appearing and atherosclerotic specimens of human arteries. Am. J. Pathol., 136, 71-80.

Campbell, R.D., Trowsdale, J. (1993). Map of the human MHC. Immunol. Today, 14, 349-352.

Cascino, I., Galeazzi, M., Salvetti, M., Ristori, G., Morozzi, G., Richardi, P.M., Tosi, R. (1994). HSP70-1 promoter region polymorphism tested in three autoimmune diseases. Immunogenetics, 39, 291-293.

Cascino, I., Sorrentino, R., Tosi, R. (1993). Strong genetic association between HLA-DR3 and a polymorphic variation in the regulatory region of the HSP70-1 gene. Immunogenetics, 37, 177182.

Cunniff, N.F., Wagner, J., Morgan, W.D., (1991). Modular recognition of 5-base-pair DNA sequence motifs by human heat shock transcription factor. Mol. Cell. Biol., 11, 3504-3514.

Currie R.W., (1987). Effects of ischemia and perfusion temperature on the synthesis of stressinduced (heat shock) proteins in isolated and perfused rat hearts. J. Mol. Cell. Cardiol., 19, 795808.

Currie, R.W., Karmazyn, M., Kloc, M., Mailer, K. (1988). Heat-shock response is associated with enhanced postischemic ventricular recovery. Circ. Res., 63, 543-549.

Currie, R.W., White, F.P. (1983). Characterization of the synthesis and accumulation of a 71-kilodalton protein induced in rat tissues after hyperthermia. Can. J. Biochem. Cell. Biol., 61, 438-446.

Day, I.N.M.D., Bolla, M., Haddad, L., O’Dell, S., Humphries, S.E. (1996). Microtiter array diagonal electrophoresis (MADGE) for population scale genotype analyses. In: Elles R.(ed.) Molecular diagnosis of genetic diseases. Totawa, New Jersey: Humana Press Inc., pp269-281.

De Santis, P., Palleschi, A., Savino, M., Scipioni, A. (1988). A theoretical model of DNA curvature. Biosphys. Chem., 32, 305-317.

Hamet, P. (1992). Abnormal hsp70 gene expression: its potential key role in metabolic defects in hypertension. Clin. Exp. Pharmacol. Physiol., Suppl. 1992, 53-59.

Hamet, P., Malo, D., Hashimoto, T., Tremblay, J. (1990a). Heat stress genes in hypertension. J. Hypertens., Suppl. 8, S47-52. 
Hamet, P., Malo, D., Tremblay, J. (1990b). Increased transcription of a major stress gene in spontaneously hypertensive mice. Hypertension, 15, 904-908.

Hamet ,P., Sun, Y.L., Malo, D., Kong, D., Kren, V., Pravenec, M., Kunes, J., Dumas, P., Richard, L., Gagnon, F., et al. (1994). Genes of stress in experimental hypertension. Clin. Exp. Pharmacol. Physiol., 21, 907-911.

Hamet, P., Tremblay, J., Malo, D., Kunes, J., Hashimoto, T. (1990c). Genetic hypertension in characterized by the abnormal expression of a gene localized in major histocompatibility complex HSP70. Transplant Proc., 22, 2566-2567.

Harrison, G.S., Drabkin, H.A., Kao, F.T., Hartz, J., Hart, I.M., Chu, E.H., Wu, B.J., Morimoto, R.I. (1987). Chromosomal location of human genes encoding major heat-shock protein HSP70. Somat. Cell. Mol. Genet., 13, 119-130.

Johnson, A.D., Berberian, P.A., Tytell, M., Bond, M.G. (1995). Differential distribution of 70-kD heat shock protein in atherosclerosis. Its potential role in arterial SMC survival. Arterioscler. Thromb. Vasc. Biol., 15, 27-36.

Kunes, J., Poirier, M., Tremblay, J., Hamet, P. (1992). Expression of hsp70 gene in lymphocytes from normotensive and hypertensive humans. Acta. Physiol. Scand., 146, 307-311.

Kunkel, L.M., Smith, K.D., Boyer, S.H., Borgaonkar, D.S., Wachtel, S.S., Miller, O.J., Breg, W.R., Jones, H.W. Jr., Rary, J.M. (1977). Analysis of human Y-chromosome-specific reiterated DNA in chromosome variants. Proc. Natl. Acad. Sci. USA, 74, 1245-1249.

Marber. M.S.. Latchman, D.S., Walker, J.M., Yellon, D.M. (1993). Cardiac stress protein elevation 24 hours after brief ischemia or heat stress is associated with resistance to myocardial infarction. Circulation, 88, 1264-1272.

Miller, G.J., Bauer, K.A., Barzegar, S., Cooper, J.A., Rosenberg, R.D. (1996). Increased activation of the haemostatic system in men at high risk of fatal coronary heart disease. Thromb. Haemost., 75, 767-771.

Miller, S.A., Dykes, D.D., Polesky, H.F. (1988). A simple salting out procedure for extracting DNA from human nucleated cells. Nucleic Acids Res., 16, 1215.

Milner, C.M., Campbell, R.D. (1990). Structure and expression of the three MHC-linked HSP70 genes. Immunogenetics, 32, 242-251.

Murry, C.E., Jennings, R.B., Reimer, K.A. (1986). Preconditioning with ischemia, a delay of lethal cell injury in ischemic myocardium. Circulation, 74, 1124-1136.

Parra, H.J., Arveiler, D. Evans, A.E., Cambou, J.P., Amouyel, P., Bingham, A., McMaster, D., Schaffer, P., Douste Blazy, P., Luc, G., et al. (1992). A case-control study of lipoprotein particles in two populations at contrasting risk for coronary heart disease. The ECTIM study. Arterioscler. Thromb., 12, 701-707.

Pelham H.R. (1986). Speculations on the functions of the major heat shock and glucose-regulated proteins. Cell, 46, 959-961.

Risch, N., Merikangas, K. (1996). The future of genetic studies of complex human diseases. Science, 273, 1516-1517.

Ritossa, F.M. (1962). A new puffing pattern induced by a temperature shock and DNP in Drosophila. Experientia, 18, 571-573.

Sargent, C.A., Dunham, I., Trowsdale, J., Campbell, R.D. (1989). Human major histocompatibility complex contains genes for the major heat shock protein HSP70. Proc. Natl. Acad. Sci. USA, 86, 1968-1972.

Tissieres, A., Mitchel, H.K., Tracy, U.M. (1974). Protein synthesis in salivary glands of Drosophila melanogaster: relation to chromosome puffs. J. Mol. Biol., 84, 389-398.

Yellon, D.M., Marber, M.S. (1994). Hsp70 in myocardial ischaemia. Experientia, 50, 1075-1084.

Yellon, D.M., Pasini, E., Cargnoni, A., Marber, M.S., Latchman, D.S., Ferrari, R. (1992). The protective role of heat stress in the ischaemic and reperfused rabbit myocardium. J. Mol. Cell. Cardiol., 24, 895-907. 


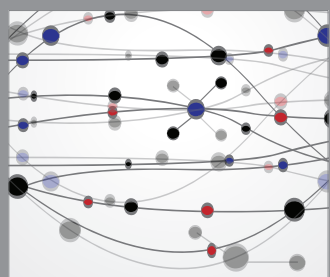

The Scientific World Journal
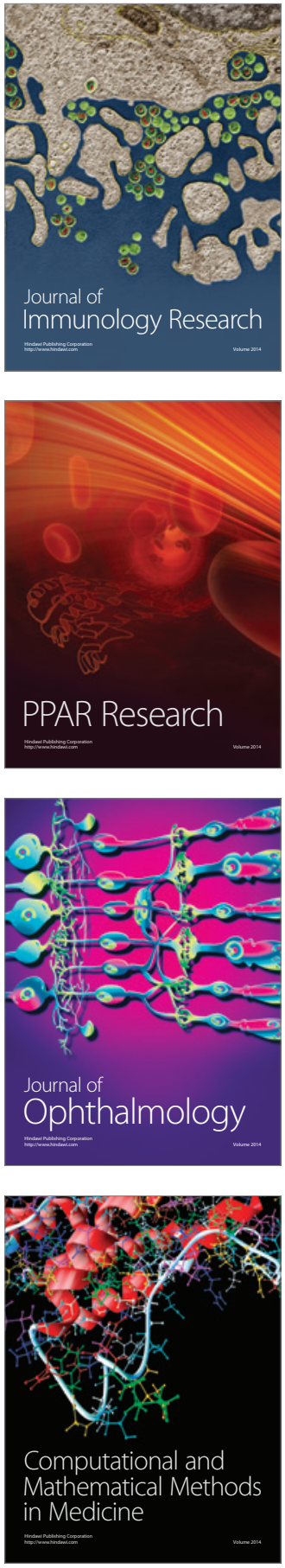

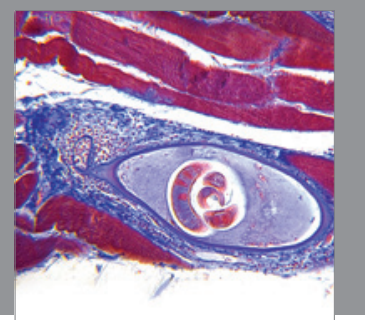

Gastroenterology

Research and Practice
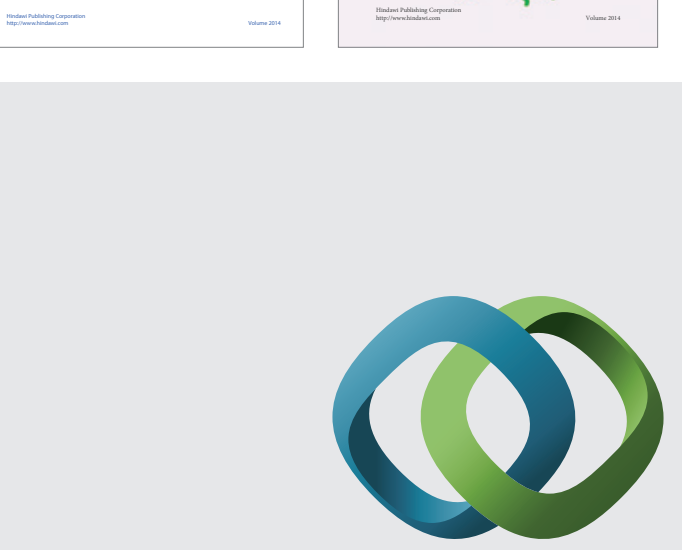

\section{Hindawi}

Submit your manuscripts at

http://www.hindawi.com
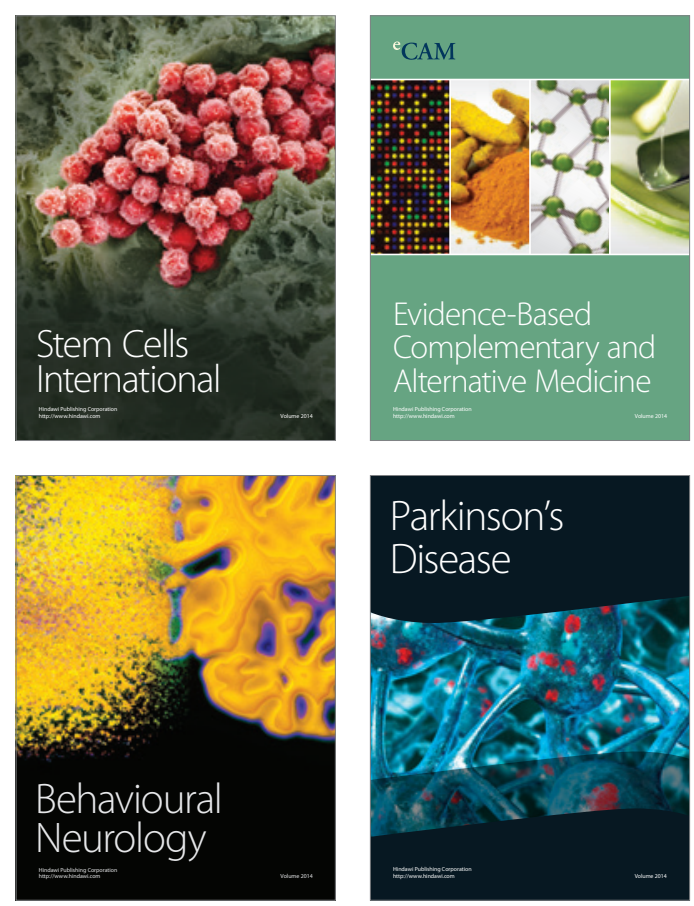

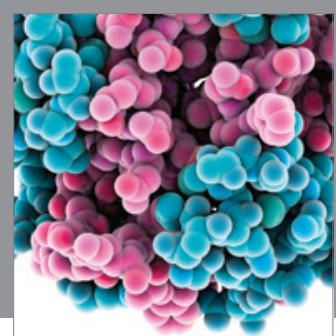

Journal of
Diabetes Research

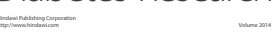

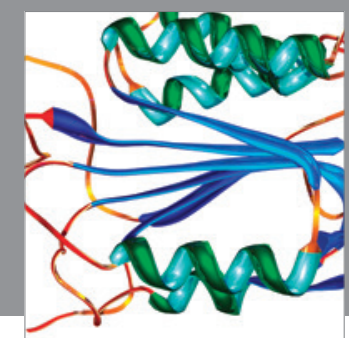

Disease Markers
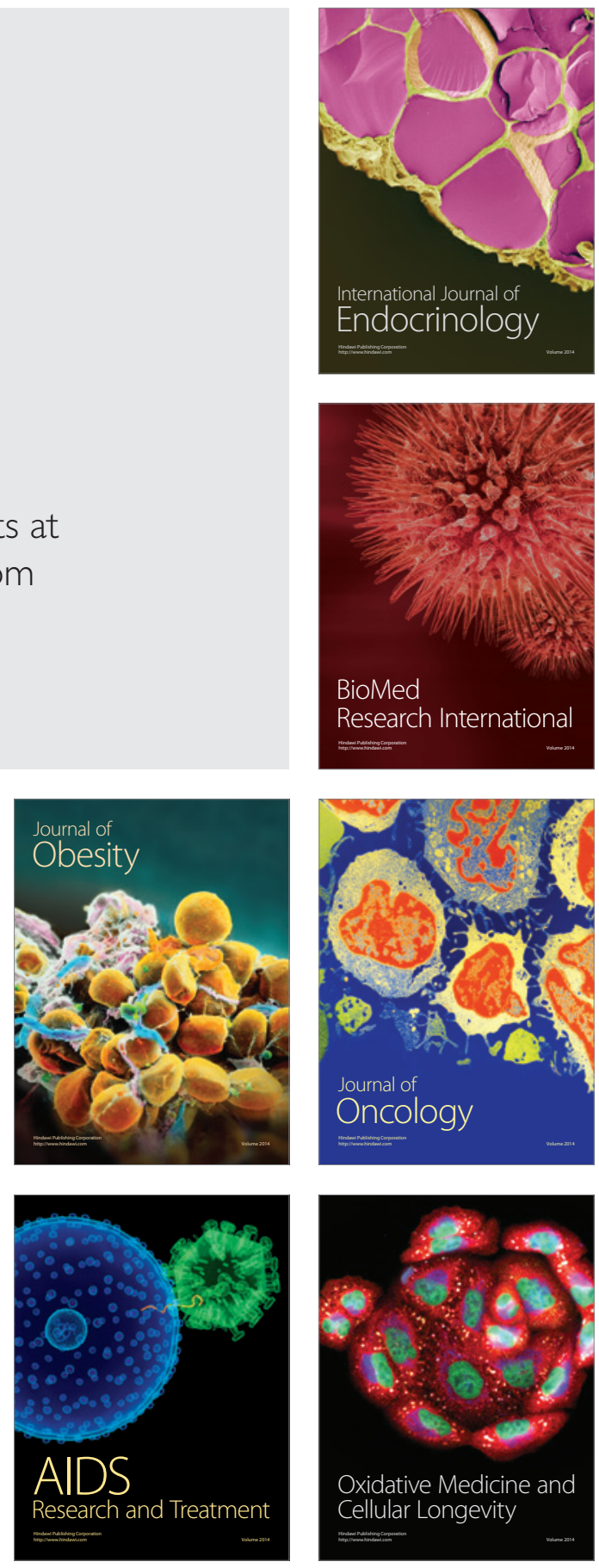